\title{
The Impact of Income Inequality on Economic Growth: Empirical Evidence from the Organization for Economic Co-operation and Development Member Countries
}

\author{
Jihène Sbaouelgi ${ }^{1}$, Ghazi Boulila ${ }^{2}$ \\ ${ }^{1}$ Doctor in High School of Economics and Commerce Sciences of Tunis, TUNISIA, Department of Economics \\ ${ }^{2}$ Professor in High School of Economics and Commerce Sciences, Tunisia, PS2D. Department of Economics
}

\begin{abstract}
The objective of this article is to quantify the transmission channels of income inequality on economic growth for Organization for Economic Co-operation and Development member countries. We try to determine what is the most important channel through which income inequality affects growth. To do this, we will estimate our basic model with variable rates. Then, we will use a simultaneous equations model to decompose the direct and indirect effects of income inequality on economic growth. According to the results, corruption is the most important channel, while trade openness channel is the least important.
\end{abstract}

Keywords: income inequality, economic growth, transmission channels, corruption

\section{Introduction}

The major economic problem in the world is the fight against poverty. In fact, it is necessary to take into account two aspects: economic growth and income inequality. There must be policy targets for effective redistribution of wealth in order to promote growth. This encourages the state to invest more in different sectors such as education, health, infrastructure, etc... This allows subsequently stimulating growth and then to slow down poverty. Economic researches on the study of the relationship between income inequality and growth have always held an important place in research developing economy. However, they are contradictions in economic thinking. Some economists suggest that unequal distribution of income stimulates economic growth. While others say that income inequality decreases growth and contributes to increase poverty. In addition, Kuznets (1955) [13], known by the famous inverted- $U$, connects the national per capita income and inequality. He says that the increase in productivity in the modern sector without redistribution in favor of the rural sector, led to a more unequal distribution of income. The Kuznets hypothesis postulates that an increase in inequality during the first period is followed by a decline since the late nineteenth or early twentieth century.

\section{Experimental Section}

Basically on the model of Mo Pak Hung (2009)[18], we will empirically analyze the direct and indirect effects of income inequality on growth through five channels: human capital (Human), financial liberalization (Cp), political stability (Stab), corruption (Icp) and trade liberalization (Trade).The variables used are:

1- Dependant variable GR : growth rate of GDP per capita

2- Gini : Gini index

3- Y60 : initial GDP per capita

4- IY : the investment share of real GDP per capita

5- PopG : the growth rate of the population

6- Pright : index of political rights

7- Stab : measure of political instability

8- Human : the average years of schooling for the population over 15 years

9- Gov : the government as a \% of GDP

10- IPC : Index of perception of corruption

11- Trade : Sum of exports and imports of goods and services as a $\%$ of GDP

12- CP : Private domestic credit as a \% of GDP

13- Inf : Inflation relative to GDP

1: Growth Regressions: 2SLS estimation

\begin{tabular}{|l|c|c|c|c|c|c|}
\hline & $(1)$ & $(2)$ & $(3)$ & $(4)$ & $(5)$ & $(6)$ \\
\hline Constant & 2,0770 & 2,8850 & 0,4150 & $-1,5445$ & $-1,0069$ & 1,3225 \\
& $(0,45)^{*}$ & $(0,83)$ & $(1,61)$ & $(-0,53)$ & $(-0,32)$ & $(0,45)$ \\
\hline Ly60 & $-1,0522$ & $-0,0069$ & $-0,2295$ & $-0,1963$ & $-0,1777$ & $-0,2116^{*}$ \\
& $(-0,48)$ & $(-0,52)$ & $(-0,66)$ & $(-0,65)$ & $(-0,72)$ & $(-1,82)$ \\
& & & & & & $-0,0043$ \\
& & & $-0,0132$ & 0,1326 & 0,0660 & $(0,18)$ \\
\hline Gini & $-0,0882$ & $-0,0652$ & $(-0,38)$ & $(0,74)$ & $(0,53)$ & $-0,1148$ \\
& $(-2,88)^{* *}$ & $(-1,25)$ & 0,0233 & $-0,1472$ & $-0,2467$ & $(-0,32)$ \\
\hline Human & & 0,0775 & $(0,46)$ & $(-0,37)$ & $-0,45)$ \\
\hline PopG & & & $-0,5767$ & $-0,4014$ & $-0,5231$ & $-0,5172$ \\
& & & $(-1,32)$ & $(-0,32)$ & $(-1,17)$ & $(-1,23)$ \\
\hline IPC & & & & $0,2775^{* *}$ & $0,2212 *$ & $-0,0657$ \\
\hline
\end{tabular}

Volume 5 Issue 1, January 2016 
International Journal of Science and Research (IJSR)

ISSN (Online): 2319-7064

Index Copernicus Value (2013): 6.14 | Impact Factor (2014): 5.611

\begin{tabular}{|c|c|c|c|c|c|c|}
\hline & & & & $(2,34)$ & $(0,72)$ & $(-0,45)$ \\
\hline IY & & & & & $\begin{array}{r}0,0333 \\
(1,17)\end{array}$ & $\begin{array}{l}0,0121 \\
(1,22)\end{array}$ \\
\hline $\mathrm{CP}$ & & & & & & $\begin{array}{c}0,0293^{*} \\
(1,45) \\
\end{array}$ \\
\hline Obs & 68 & 67 & 66 & 65 & 66 & 65 \\
\hline $\mathrm{R}^{2}$ & (.) & (.) & 0,123 & 0,123 & 0,155 & 0,253 \\
\hline
\end{tabular}

Note: The symbols ***, **, * represent significance levels of the coefficients at 1\%, 5\% and 10\% respectively. Figures in brackets are standard deviations corrected for heteroscedasticity when the Pagan-Hall test is significant.

\begin{tabular}{|c|c|c|c|c|c|}
\hline & (7) & (8) & (9) & $(10)$ & $(11)$ \\
\hline Constant & $\begin{array}{l}1,7643 \\
(0,83)\end{array}$ & $\begin{array}{l}2,5457 \\
(1,29)\end{array}$ & $\begin{array}{c}2,6571 * \\
(1,82) \\
\end{array}$ & $\begin{array}{l}4,6529 \\
(1,53) \\
\end{array}$ & $\begin{array}{c}4,7623 \\
(1,73) \\
\end{array}$ \\
\hline $\mathrm{Ly}_{60}$ & $\begin{array}{c}-0,2543^{*} \\
(-1,90)\end{array}$ & $\begin{array}{c}-0,2991^{*} \\
(-1,91)\end{array}$ & $\begin{array}{c}-0,1457^{* *} \\
(-2,00)\end{array}$ & $\begin{array}{c}-0,3296 * * \\
(-2,37)\end{array}$ & $\begin{array}{c}-0,3468^{* *} \\
(-2,43)\end{array}$ \\
\hline Gini & $\begin{array}{c}-0,0074 \\
(-0,27)\end{array}$ & $\begin{array}{l}-0,0014 \\
(-0,03)\end{array}$ & $\begin{array}{c}-0,00976 \\
(-0,45)\end{array}$ & $\begin{array}{c}-0,0081 \\
(-0,12)\end{array}$ & $\begin{array}{c}-0,0052 \\
(-0,25)\end{array}$ \\
\hline Human & $\begin{array}{l}-0,0547 \\
(-0,45)\end{array}$ & $\begin{array}{l}-0,1356 \\
(-0,73)\end{array}$ & $\begin{array}{c}-0,1752 \\
(-1,16)\end{array}$ & $\begin{array}{c}-0,2376 \\
(-1,27)\end{array}$ & $\begin{array}{c}-0,0432 \\
(-1,43)\end{array}$ \\
\hline PopG & $\begin{array}{c}-0,4765 \\
(-0,76)\end{array}$ & $\begin{array}{c}-0,6372 \\
(-0,67)\end{array}$ & $\begin{array}{l}-0,9345 \\
(-0,75)\end{array}$ & $\begin{array}{l}-0,3451 \\
(-0,32)\end{array}$ & $\begin{array}{c}-0,8398 \\
(-0,53)\end{array}$ \\
\hline IPC & $\begin{array}{r}-0,0547 \\
(-0,34) \\
\end{array}$ & $\begin{array}{l}-0,1135 \\
(-0,45) \\
\end{array}$ & $\begin{array}{c}-0,0724 \\
(-0,33) \\
\end{array}$ & $\begin{array}{c}-0,1747 \\
(-0,45) \\
\end{array}$ & $\begin{array}{c}-0,2436 \\
(-0,65)\end{array}$ \\
\hline IY & $\begin{array}{r}0,4366 \\
(1,30)\end{array}$ & $\begin{array}{r}0,0532 \\
(1,32)\end{array}$ & $\begin{array}{l}0,0254 \\
(1,33)\end{array}$ & $\begin{array}{l}0,6577 \\
(1,24)\end{array}$ & $\begin{array}{l}0,3462 \\
(1,32)\end{array}$ \\
\hline $\mathrm{CP}$ & $\begin{array}{c}0,0233^{* *} \\
(1,88) \\
\end{array}$ & $\begin{array}{c}0,0254^{* *} \\
(1,54) \\
\end{array}$ & $\begin{array}{c}0,0265^{*} \\
(1,62) \\
\end{array}$ & $\begin{array}{l}0,0222 \\
(1,23) \\
\end{array}$ & $\begin{array}{l}0,0287 \\
(1,25) \\
\end{array}$ \\
\hline Gov & $\begin{array}{c}-0,1165^{* *} \\
(-2,45)\end{array}$ & $\begin{array}{c}-0,1263 * * \\
(-2,22)\end{array}$ & $\begin{array}{c}-0,1658^{* *} \\
(-2,26)\end{array}$ & $\begin{array}{c}-0,1432 * * \\
(-2,16)\end{array}$ & $\begin{array}{c}-0,1167 * * \\
(-2,16)\end{array}$ \\
\hline Stab & & $\begin{array}{l}0,0843 \\
(0,26)\end{array}$ & $\begin{array}{c}0,0143 \\
(0,02)\end{array}$ & $\begin{array}{c}-0,2432 \\
(-0,65)\end{array}$ & $\begin{array}{c}-0,4532 \\
(-0,26)\end{array}$ \\
\hline Trade & & & $\begin{array}{c}0,0043 \\
(0,73)\end{array}$ & $\begin{array}{c}0,0048 \\
(0,66)\end{array}$ & $\begin{array}{l}0,0015 \\
(0,65)\end{array}$ \\
\hline Pright & & & & $\begin{array}{c}-0,5438^{* *} \\
(-2,13)\end{array}$ & $\begin{array}{c}-0,3765 * * \\
(-2,15)\end{array}$ \\
\hline Inf & & & & & $\begin{array}{l}-0,0015 \\
(-0,65)\end{array}$ \\
\hline Obs & 65 & 64 & 65 & 65 & 65 \\
\hline $\mathrm{R}^{2}$ & 0,265 & 0,354 & 0,384 & 0,387 & 0,354 \\
\hline
\end{tabular}

Note: The symbols $* * *, * *, *$ represent significance levels of the coefficients at $1 \%, 5 \%$ and $10 \%$ respectively. Figures in brackets are standard deviations corrected for heteroscedasticity when the Pagan-Hall test is significant

\begin{tabular}{|c|c|c|c|c|c|c|}
\hline Tests & $(1)$ & $(2)$ & $(3)$ & $(4)$ & $(5)$ & $(6)$ \\
\hline F stat & $4,06^{* *}$ & $3,52^{* *}$ & 2,80 & $4,43^{* *}$ & 1,49 & $3,98^{* *}$ \\
\hline DWH $\left(\chi^{2}(1)\right)$ & 0,18 & 0,202 & 0,024 & 0,14 & 0,04 & 0,28 \\
\hline Pagan-Hall $\left(\chi^{2}(\mathrm{q})\right)$ & 2,64 & 4,72 & 4,14 & 2,55 & 3,21 & 3,41 \\
\hline Sargan $\left(\chi^{2}(1)\right)$ & 2,44 & 0,22 & 0,56 & 0,42 & 0,19 & 0,18 \\
\hline Tests & $(7)$ & $(8)$ & $(9)$ & $(10)$ & $(11)$ & \\
\hline F stat & $3,72^{* *}$ & $4,33^{* *}$ & $4,65^{* *}$ & $3,76^{* *}$ & $3,29^{* *}$ \\
\hline DWH $\left(\chi^{2}(1)\right)$ & 0,65 & 0,23 & 0,26 & 0,08 & 0,04 \\
\hline Pagan-Hall $\left(\chi^{2}(\mathrm{q})\right)$ & 5,12 & 5,22 & 5,05 & 3,82 & 4,54 \\
\hline Sagan $\left(\chi^{2}(1)\right)$ & 0,25 & 0,22 & 0,14 & 0,01 & 0,001 \\
\hline
\end{tabular}

\section{- Interpretations}

$\square$ Fisher statistics :Fisher test allows knowing if a multiple regression model is globally significant or not. Except the equations (3) and (5), tests of other equations are significant. In addition, the values associated with the probability of Fisher are less than 0.05 . So, we accept the alternative hypothesis $\mathrm{H}_{1}$ whish confirms the global significance of the model.
Durbin-Wu-Hausman: This test was conducted in two stages least squares regressions to ensure that the Gini coefficient is actually disencumbered of the part of endogenous after the introduction of the instruments. According to the results, the DWH test is not significant, Fcalculed $<$ Ftheorical so we accept $\mathrm{H}_{0}$ which means the absence of endogeneity of the Gini coefficient. So, in order to have consistent and unbiased estimators, we must use the 


\section{International Journal of Science and Research (IJSR) \\ ISSN (Online): 2319-7064}

Index Copernicus Value (2013): 6.14 | Impact Factor (2014): 5.611

method of 2sls. In another words, we must introduce valid instrumental variables.

$\square$ Pagan-Hall: This test is performed to check the constancy (homoscedasticity) of the residues in regressions with two stages least squares. According to the results, all chi-square statistics are not significant. Thus we accept the null hypothesis of homoskedasticity. So, to verify the validity of the instruments we should applied the Sargan statistics.

$\square$ Sargan: According to the results, all the coefficients are not significant. So, we accept $\mathrm{H} 0$ which confirms the validity of the instruments.

$\Delta$ In table 2, confirmed the negative effect of income inequality on growth respecting the assumptions of the transmission channels. In the next section, we will test the empirical effects of income inequality on each determinant of growth (transmission channel).

\section{The Effect of Income Inequality on Transmission Channels}

To detect the importance of transmission mechanisms, we estimate the effect of income inequality on human capital, political stability, corruption, financial liberalization and trade liberalization. This step captures the indirect effect of income inequality on growth. First, we will estimate the dependence of the transmission variables on the measurement of income inequality(Gini): $Z^{i}=\beta_{0}+\beta_{1} \operatorname{gini}^{i}+\mu$ (a)

With $\beta 0$ is the coefficient associated to the constant, $\beta 1$ is the coefficient associated to the variable « gini » and $\mathrm{Zi}$ represents the vector associated to the different transmission channels. To test the robustness of our results, we use an alternative specification for the transmission channels. To do this we incorporate the variable "initial level of real GDP per capita" in equation (a).

The equation that describes the transmission variables: $\mathrm{Z}^{\mathrm{i}}=\lambda_{0}+\lambda_{1} \operatorname{Ln}\left(\mathrm{Y}_{0}^{\mathrm{j}}\right)+\lambda_{2} \operatorname{gini}^{\mathrm{i}}+\sigma^{\mathrm{i}}(\mathrm{b})$

$\mathrm{Zi}$ represents the vector of transmission channels; $\lambda 0, \lambda 1$ and $\lambda 2$ are coefficients that reflect the influence of the constant, the effect of initial income per capita and that of income inequality on the transmission channel concerned. Since the Gini coefficient explains some of the variation in transmission variables. Then it will be possible to calculate the direct and indirect effect of income inequality on economic growth. So $G^{i}=\left(\alpha_{0}+\alpha_{3} \beta_{0}\right)+\alpha_{1} \operatorname{Ln}\left(Y_{0}^{i}\right)+\left(\alpha_{2}+\alpha_{3}\right.$ $\left.\beta_{1}\right)$ gini $^{\mathrm{i}}+\alpha_{3} \mu^{\mathrm{i}}+\varepsilon^{\mathrm{i}}(\mathrm{c})$

Table 2: Indirect Transmission Channels of Income Inequality

\begin{tabular}{|lccccc|}
\hline & Stab & Human & Trade & Cp & Ipc \\
\hline Constant & 0,0445 & $7,7649^{* * *}$ & $43,6545^{* *}$ & 15,6533 & $5,4653^{* *}$ \\
& $(-0,03)$ & $(3,65)$ & $(3,12)$ & $(0,76)$ & $(2,49)$ \\
Ly 60 & 0,2435 & 0,7634 & 2,9562 & $6,5772^{* *}$ & 0,0461 \\
& $(1,37)$ & $(1,61)$ & $(0,83)$ & $(2,83)$ & $(1,66)$ \\
Gini & $-0,0762^{*}$ & $-0,0726^{* * *}$ & $-0,1850$ & $-0,7948^{*}$ & $-0,1286^{* *}$ \\
& $(-1,98)$ & $(-2,87)$ & $(-0,46)$ & $(-1,85)$ & $(2,62)$ \\
Obs & 77 & 68 & 76 & 77 & 77 \\
& & & & & \\
$\mathrm{R}^{2}$ & 0,076 & 0,133 & 0,076 & 0,153 & 0,146 \\
Breusch-Paga & 0,01 & 0,51 & 5,76 & 2,24 & 4,87 \\
\hline
\end{tabular}

Estimated with OLS considering that Stab, Human, Trade, Cp and Ipc are respectively dependent variables.

Note *,**,*** correspond to significance at the 10, 5 and $1 \%$.

The results of the different regressions show that there is a significant negative correlation between the Gini index, and political stability, human capital, financial liberalization and corruption. So, income inequality has a negative and significant effect on these transmission channels. In contrast, the relationship between the Gini index and trade openness is negative but not significant. This result may be due to the presence of the initial level of per capita income as an explanatory variable. For this reason, we estimate again equation (b) with elimination of the initial level of GDP per capita. The results are presented in Table (3).

Table 3: Gini index and transmission channels: Estimation with OLS

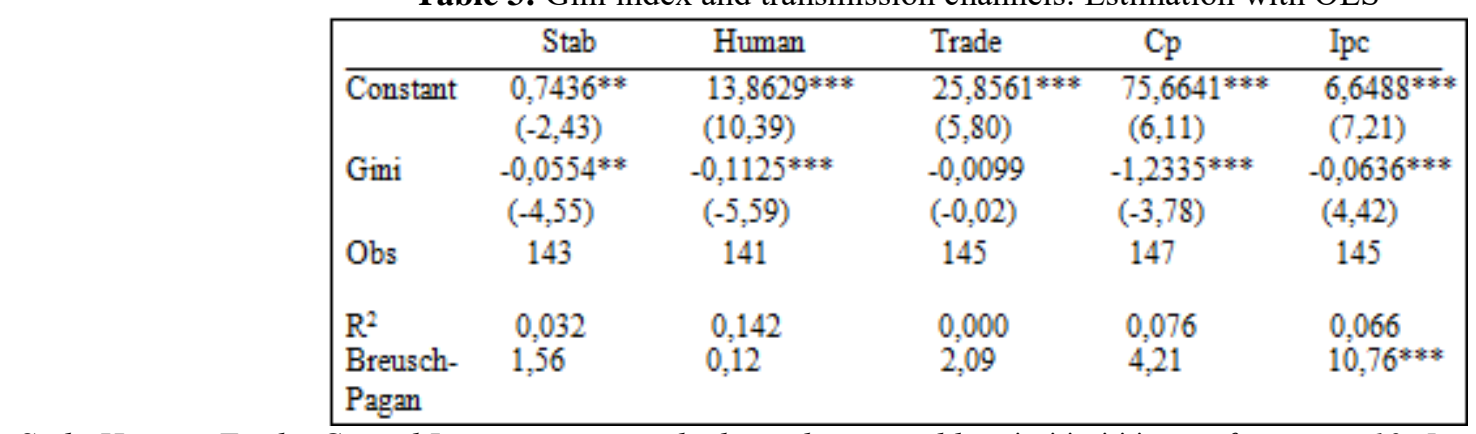

Stab, Human, Trade, Cp and Ipc are respectively dependent variables. *, **, *** significance at 10, 5, and 1\% 


\section{International Journal of Science and Research (IJSR) \\ ISSN (Online): 2319-7064 \\ Index Copernicus Value (2013): 6.14 | Impact Factor (2014): 5.611}

After eliminating the initial level of real GDP per capita, we note that the results are almost the same interpretations as those in the previous table. So it is confirmed that the Gini coefficient has a negative and insignificant effect on trade liberalization. To test the robustness of our results, we will estimate equation (b) using the 2 sls method.

Table 4: Gini index and transmission channels: Estimation with 2SLS

\begin{tabular}{|ll|l|l|l|l|}
\hline & Stab & Human & Trade & Cp & Ipc \\
\hline Constant & $2,567^{* *}$ & $11,554^{* * *}$ & $60,657^{* *}$ & $90,543^{* * *}$ & $20,566^{* * *}$ \\
& $(4,17)$ & $(3,57)$ & $(2,99)$ & $(2,98)$ & $(4,57)$ \\
Ly60 & 0,066 & 0,446 & $-0,623$ & 4,854 & 0,540 \\
& $(0,23)$ & $(0,81)$ & $(-0,02)$ & $(1,54)$ & $(0,64)$ \\
Gini & $-0,044^{* * *}$ & $-0,247^{* * *}$ & $-0,368$ & $-2,481^{* *}$ & $-0,357^{* * *}$ \\
& $(-5,73)$ & $(-4,29)$ & $(-0,75)$ & $(-2,11)$ & $(-3,45)$ \\
Obs & 67 & 66 & 67 & 73 & 67 \\
F & $6,85^{* * *}$ & $14,60^{* * *}$ & $5,26^{* *}$ & $6,31^{* * *}$ & $8,40^{* * *}$ \\
DWH & $11,67^{* * *}$ & $5,16^{* *}$ & 5,73 & $6,41^{* *}$ & $11,02^{* * *}$ \\
Pagan-Hall & 2,19 & 2,46 & 3,55 & 7,92 & 4,04 \\
Sargan & 2,76 & 1,81 & $5,65^{* *}$ & 2,73 & 3,18 \\
\hline
\end{tabular}

Stab, Human, Trade, Cp and Ipc are respectively dependent variables. *, **, *** significance at 10, 5, and 1\%.

Table 4 shows that income inequality has a negative and significant impact on the transmission channels except channel of trade openness. And that may be the cause of the existence of the variable "LY 60 ". For this reason, we will estimate again the regression regardless this variable to check the robustness of the results. In fact, the Fisher statistics indicate that the models are statistically significant. In addition, exception of the equation of trade openness, the
DWH test shows the endogeneity of Gini coefficient, so we had to settle for a regression with 2 sls method.

In addition, the Pagan-Hall test indicates that the residuals are homoskedastics, so we will apply the Sargan test. And this shows that the selection of instruments is valid for our regressions except for the variable "Trade" where the Gini coefficient is exogenous.

Table 5: Gini index and transmission channels: Estimation WITH 2sls

\begin{tabular}{|c|c|c|c|c|c|}
\hline & Stab & Human & Trade & $\mathrm{Cp}$ & Ipc \\
\hline Constant & $\begin{array}{l}2,756^{* *} \\
(4,80)\end{array}$ & $\begin{array}{l}15,773^{* * *} \\
(6,67)\end{array}$ & $\begin{array}{l}77,031^{* *} \\
(2,19)\end{array}$ & $\begin{array}{c}90,523 * * * \\
(5,42)\end{array}$ & $\begin{array}{c}2,661^{* * *} \\
(6,43)\end{array}$ \\
\hline Gini & $\begin{array}{l}-0,071^{* * * *} \\
(-3,57)\end{array}$ & $\begin{array}{l}-0,257 * * * \\
(-4,35)\end{array}$ & $\begin{array}{l}-1,935^{* *} \\
(-2,07)\end{array}$ & $\begin{array}{c}-3,743^{* * *} \\
(-4,56)\end{array}$ & $\begin{array}{c}-0,821 * * * \\
(-5,99)\end{array}$ \\
\hline $\begin{array}{l}\mathrm{Obs} \\
\mathrm{F}\end{array}$ & $\begin{array}{c}115 \\
15.62^{* * *}\end{array}$ & $\begin{array}{c}104 \\
26.40^{* * * *}\end{array}$ & $\begin{array}{c}116 \\
5.99^{* * *}\end{array}$ & $\begin{array}{c}116 \\
10,53^{* * *}\end{array}$ & $\begin{array}{c}121 \\
15,63 * * *\end{array}$ \\
\hline $\begin{array}{l}\text { DWH } \\
\text { Pagan-Ha }\end{array}$ & $\begin{array}{l}18,81^{* * * *} \\
\text { all } 76\end{array}$ & $\begin{array}{c}13,54 * * * \\
6,51\end{array}$ & $\begin{array}{l}0,15 \\
1,97\end{array}$ & $\begin{array}{c}14,09 * * \\
3,25\end{array}$ & $\begin{array}{l}21,90^{* * *} \\
2,55\end{array}$ \\
\hline Sargan & 1,75 & 1,41 & $3,71 * *$ & 1,28 & 0,62 \\
\hline
\end{tabular}

Note that Stab, Human, Trade, Cp and Ipc are respectively dependent variables. ${ }^{*}, * *, * * *$ Correspond to the significance at 10,5 , and $1 \%$.

We conclude that the indirect effects of income inequality on economic growth are confirmed. The Gini coefficient has a negative and significant effect on all variables. Thus, human capital, political stability, financial liberalization, trade openness and corruption are the transmission channels through which income inequality affects growth. In the next section, we will quantify the relative contribution of each transmission channel.

Table 6: The importance of transmission channels

\begin{tabular}{|c|c|c|c|c|c|}
\hline Variables & Direct Effect & \multicolumn{2}{|c|}{ Indirect Effect } & Contribution & Relative Contribution \\
\hline & $\alpha_{2}$ & $\alpha_{3}$ & $\beta_{2}$ & $\alpha_{2}+\alpha_{3} \beta_{2}$ & $\%$ \\
\hline Gini & $-0,0163$ & & & $-0,0143$ & $6 \%$ \\
\hline Stab & & 0,2653 & $-0,0164$ & $-0,0084$ & $3,6 \%$ \\
\hline Human & & $-0,9645$ & $-0,0872$ & 0,0163 & $10,2 \%$ \\
\hline Trade & & 0,0254 & $-0,1734$ & $-0,0005$ & $2,3 \%$ \\
\hline $\mathrm{Cp}$ & & $-0,0577$ & $-0,7843$ & 0,0642 & $23 \%$ \\
\hline Icp & & $-2,2734$ & $-0,0945$ & 0,1566 & $75,5 \%$ \\
\hline Total & & & & 0,1462 & $100 \%$ \\
\hline
\end{tabular}




\section{International Journal of Science and Research (IJSR) \\ ISSN (Online): 2319-7064}

Index Copernicus Value (2013): 6.14 | Impact Factor (2014): 5.611

This table presents the calculation of the relative contributions of income inequality and transmission channels on economic growth. The main result that emerges from these estimates is that income inequality affects growth primarily through corruption with a relative share of $75.5 \%$ of the total effect. Trade openness is the least important channel through which income inequality affects growth with a contribution of almost $2.3 \%$ of the total effect. This result confirms the insignificant effect of the Gini coefficient on the variable "Trade" in table (2) and (4).

\section{Conclusion}

The effects of income inequality occupy a major concern of economists. In fact, based on the work of Papyrakis and Gerlagh (2006) [21] and the analytical framework developed by Mo Pak Hung (2000-2009), we analyzed the direct and indirect effects of income inequality on economic growth. Our study consist to examine the transmission channels through which inequality has an impact on growth in OECD member countries. To address the problem of endogeinisation of the Gini index, we adopted the regression with the method of two stages least squares. The results show that corruption is the most important channel, while trade liberalization is the lowest channel.

\section{References}

[1] Alesina, A. and R. Perotti, [1996]. "Income distribution, political instability, and investment". European Economic Review, 40: 1203-1228.

[2] Alesina, A. and Rodrik., [1994]. "Distributive, politics and economic growth". European Economic Review, 55: 345-367 90 Income inequality and economic growth: empirical investigations on the transmission channels

[3] Atkinson. T.[2002] « La distribution des revenus dans les pays de l'OCDE au vingtième siècle» Revue française d'économie. Volume $17 \mathrm{~N}^{\circ} 1,2002$. pp. 3-31.

[4] Atkinson, M. Glaude et L. Olier [2001] "Inégalités économiques ", Conseil d'analyse économique, La Documentation française.

[5] Barro, R., [2000]. "Inequality and growth in a panel of countries". Journal of Economic Growth, 5: 5-32.

[6] Benhabib, J. and M. Spiegel, [1994]. "The role of human capital in economic development: Evidence from aggregate cross-country data". Journal of Monetary Economics, 34: 143-173.

[7] Bourguignon., [2003]. "The difficult task of expanding the income poverty paradigm". Paper prepared for the conference on "Conceptual challenges in poverty and inequality analysis", Cornell University, 16-17 April 2002.

[8] Deininger, K., Squire, L. [1996], "Measuring Income Inequality: a New Data-base", World Bank economic Review, vol. 10(3), pp. 565-591.

[9] Deininger, K., Squire, L. [1998], "New Ways of Looking at Old Issues: Inequality and Growth", Journal of Development Economics, vol. 57(2), pp. 259-287.

[10] Forbes. K.J. [2000] " $A$ Reassessment of the Relationship Between Inequality and Growth" American Economic Review, vol 90 : pp. 869-887.
[11] Galor, Oded and Zeira, Joseph, [1993], "Income Distribution and Macroeconomics," Review of Economic Studies, 60 35-52.

[12]Kaldor, N.[1956], "Alternative Theories of Distribution," Review of Economic Studies, 23, 83-100.

[13] Kuznets, S., [1955], "Economic Growth and Income Inequality," American Economic Review, 45, 1-28.

[14] Levine, R. and Renelt, D. (1992) «Sensitivity Analysis of Cross Country Growth Regressions" American Economic Review, 82: 942-63.

[15] Mankiw, N., D. Romer and D. Weil, [1992]. "A contribution to the empirics of economic growth". Quarterly Journal of Economics 152: 407-437.

[16] Milanovic, B. 2002, "True World Income Distribution, 1988 and 1993: First Calculation Based on Household Surveys Alone", Economic Journal, vol. 112, pp. 51-92.

[17] Mo, Pak Hung, [2000]: "Income Inequality and Economic Growth," Kyklos, 53, 293-316.

[18] Mo, Pak Hung, [2001]: "Corruption and Economic Growth," Journal of Comparative Economics, 29, 6679.

[19] Mo, Pak Hung, [2003]: “Land Distribution Inequality and Economic Growth: Transmission Channels and Effects," Pacific Economic Review 8: 171-181.

[20] Mo, Pak Hung, [2009]: "Income Distribution Polarization and Economic Growth: Channels and Effects," Indian Economic Review, 44, 107-123.

[21] Papyrakis, E. and Gerlagh, R. (2006) "The Resource Curse Hypothesis and its Transmission Channels" Journal of Comparative Economics , 32: 181-193

[22]Perotti, R., [1993]. "Income distribution and investment". European Economic Review, 38: 827-835.

[23] Perotti, Roberto, [1994]: "Income Distribution and Investment," European Economic Review, 38, 827-35.

[24] Piketty. T and Saez. E [2003] "Income Inequality in the United States, 1913- 1998”, Quarterly Journal of Economics, 118(1): 1-39.

[25] Ross Levine; David Renelt "A Sensitivity Analysis of Cross-Country Growth Regressions" The American Economic Review, Vol. 82, No. 4. (Sep., 1992),pp. 942963.

[26] World Bank., [2013]. World development indicators database. 